Journal of Teacher Education for Sustainability, vol. 23, no. 1, pp. 99-114, 2021

\title{
What Does Education for Sustainable Development Offer in Initial Teacher Training? A Systematic Review
}

\author{
$\mathrm{M}^{\mathrm{a}}$ del Carmen Pegalajar-Palomino \\ University of Jaén, Jaén, Spain \\ Antonio Burgos-García \\ University of Granada, Granada, Spain \\ Estefania Martinez-Valdivia \\ University of Jaén, Jaén, Spain
}

\begin{abstract}
Promoting Education for Sustainable Development (ESD) in higher education implies an improvement and quality in the exercise of responsible citizenship, being the key in the training of future teachers as the main agent of change and transition towards sustainability in society. The aim of this study is to collect and analyze scientific evidence on the attitudes, competences and training of future teachers towards ESD. Therefore, a qualitative methodology has been carried out based on a systematic review of the most important scientific databases (WoS and Scopus). One of the most interesting results shows that there are favorable attitudes of our education students towards sustainability and their commitment to the environment. However, we can conclude that, in the training of our teachers, there is a deficit in the development of professional skills needed to implement ESD (teaching practice) to contribute to social welfare.
\end{abstract}

Key words: sustainability, higher education, teacher training, teacher education for sustainability, social responsability, Education for Sustainable Development

\section{Introduction}

United Nations (UN) is doing a commendable job in favor of the sustainable development of the whole planet. With the declaration of 2015, entitled "Transforming our World: The 2030 Agenda for Sustainable Development", the UN has drawn up an action plan that includes a series of Sustainable Development Goals (SDGs) to address the main social, economic and environmental challenges facing humanity. More specifically, SDG 4 refers to the promotion of quality education, with challenge 4.7 , the need for all students to acquire the knowledge and skills to promote sustainable development. 
Working on these challenges and deepen the importance-necessity of ESD, higher education is defined as a key space to offer an effective response, especially when future teachers, key agents in social transformation and progress, are trained at this institution. Following the editorial line of the Journal of Teacher Education for Sustainability (JTES) entitled "Do JTES Help us to Create Deeper Personal Meanings for Sustainable Education?" (Salite et al., 2021), this research work has as a reference the study by MurilloVargas et al. (2021) that maps the scientific production and contents associated with sustainable development goals and their integration in universities and the research by Brandisauskiene et al. (2021) that analyzes the key factors in teacher sustainable development. The importance of incorporating sustainability 'content' into curricula by adopting methodologies that encourage values education and the development of critical thinking skills in teacher education is a key and deepens the development of ideas on the phenomenon of sustainability, sustainable education and sustainable development (Salite et al., 2021). In this sense, this would bring more responsibility in decision-making, more professionalization, as well as in the adoption of sustainable and environmentally conscious approaches, behaviors, lifestyles and consumption patterns (Bertschy et al., 2013; Howlett et al., 2016; Alkhawaldeh, 2017).

\section{Education for Sustainable Development in Initial Teacher Training}

Education for Sustainable Development is an opportunity to acquire knowledge, skills and values linked to the development of an equitable lifestyle, achieving longterm positive social transformation (Öztürk, 2017; Joseph \& Said, 2019). It allows responding to the challenges of sustainable development (Sunthonkanokpong \& Murphy, 2019; Heasly et al., 2020), contributing to the present and future well-being of the global community (Odell et al., 2020).

ESD must be considered for the improvement and quality in the training of university students towards the exercise of responsible citizenship, elevating the training of future teachers to a crucial role as the main agent of change and transition towards sustainability (Albareda et al., 2018). Students in education must be able to be citizens committed to their environment and lead new challenges that contribute to the creation of a fairer and more sustainable world (Merrit et al., 2019). Their perceptions of ESD and the development of their professional competencies in sustainability influence their future teaching practice and the way they prepare their students to face the challenges of today and tomorrow (Anyolo et al., 2018; Bulut \& Cakmak, 2018).

The report "Progress in ESD and Education for Global Citizenship" (UNESCO, 2018) highlights the need to improve teacher education for building sustainable societies. Leich et al. (2018) propose that university education curricula should incorporate content related to poverty, climate change, the environment, among others, with the intention of preparing future teachers to understand the world in which they work and to face the challenges. Therefore, it is necessary for higher education institutions to make an effort to incorporate ESD as a priority for the professional development of future teachers. A commitment must be made to develop a profile of teachers as professionals whose task is to offer sustainable patterns to society and its students in order to build a more equitable and fair future for all (Darling-Hammond et al., 2017). 
Undoubtedly, it is an issue that is growing in interest among the scientific community, and further research is needed to explore the perspective of teacher education towards sustainability and the incorporation of ESD into their curricula. Therefore, the aim of this paper is to collect and analyze the scientific evidence on future teacher attitudes, competences and training towards ESD. It is important to recognize the need for the university student to acquire knowledge, skills, competences, as well as a value system that will support the transition to the development of a more sustainable society in their future professional practice.

\section{Method}

This paper proposes a systematic review of empirical research published during the period of 2010-2020 in the Web of Science (WoS) and Scopus databases as potential sources of scientific and academic information. The principles of the PRISMA declaration (Urrútia \& Bonfill, 2010) have been taken into account, as well as the standardized methodological guidelines proposed by Alexander (2020) for the elaboration of systematic quality review studies.

\section{Publication Search Strategy and Selection Criteria}

The strategy for the search of publications starts from the definition of the descriptors, being these: "sustainability", "Education for Sustainable Development", "teacher training", "social responsibility" and "social commitment". These terms have been used in the title and abstract sections and in the key words of both databases, complemented by the Bologna operators "AND" and "OR".

In the publications found, we have applied as inclusion criteria: scientific articles directly related to sustainability and initial teacher training, written in Spanish and English, published during the period of 2010-2020 and available for access to the full text. However, duplicated works, books or book chapters, communications to conferences, Doctoral Theses, Final Degree or Master Papers, theoretical studies or reviews, as well as articles not related to the central theme of this work have been excluded.

\section{Extraction of Publications and Quality Evaluation}

By using the search string in the selected databases, a total of 1399 publications have been obtained that make up the population under study. The selection of these publications has been made from an intentional sampling based on the inclusion and exclusion criteria previously described, reducing the sample to 118 publications. The final review of each work from the reading of the full text allows checking scientific quality criteria, giving rise to the final sample of the research made up of 21 publications available for analysis and synthesis of the information (Figure 1). 


\section{Figure 1}

Flow Chart for Publication Search and Sample Selection

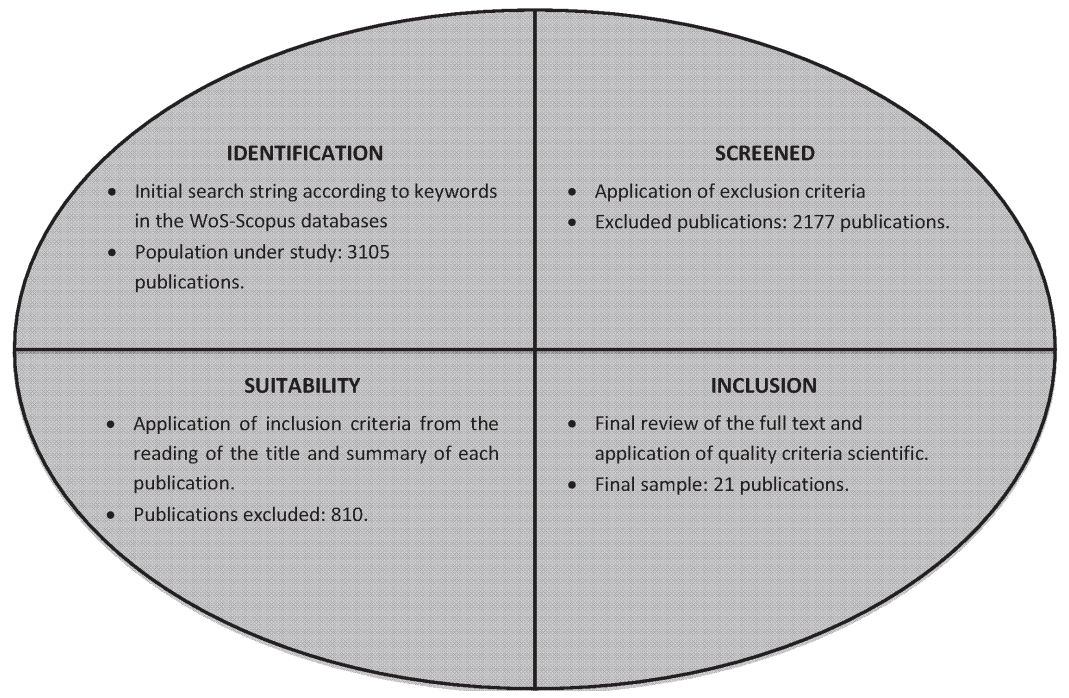

\section{Data Analysis}

The Mendeley publication management software has been used to organize the publications selected in each database. The analysis and synthesis of the information of the publications that form part of the final sample of this work have been carried out using a data template developed with the Microsoft Excel software.

\section{Results}

\section{Descriptive Analysis of Publications}

The descriptive analysis of the publications reviewed reveals that the selected studies were published between 2013 and 2020. The years 2019 and 2020 are those with the highest density of this type of studies, which demonstrates the topicality of the subject under study (Figure 2).

Most of them are articles written in English (94.4\%) and published mainly in international scientific journals such as Sustainability with a total of $61.9 \%$ and Journal of Teacher Education for Sustainability (14.3 \%), being such journals a specific dissemination center related to environmental, cultural, economic and social sustainability of human beings. However, publications in other journals have also been analyzed as related to the topic of study, or to educational topics in general, such as: International Journal of Sustainability in Higher Education (4.8 \%), Romanian Journal for Multidimensional Education (9.5 \%), Uniciencia (4.8 \%) and Foro de Educación $(4.8 \%$ ) (Figure 3). 
Figure 2

Number of Articles per Year

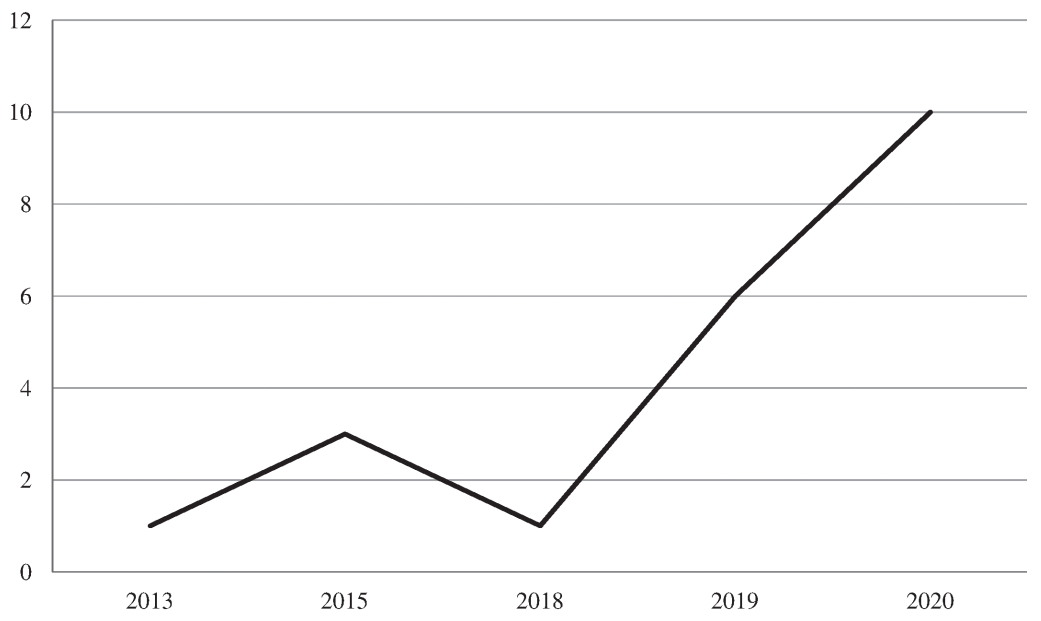

Figure 3

Number of Articles per Journal

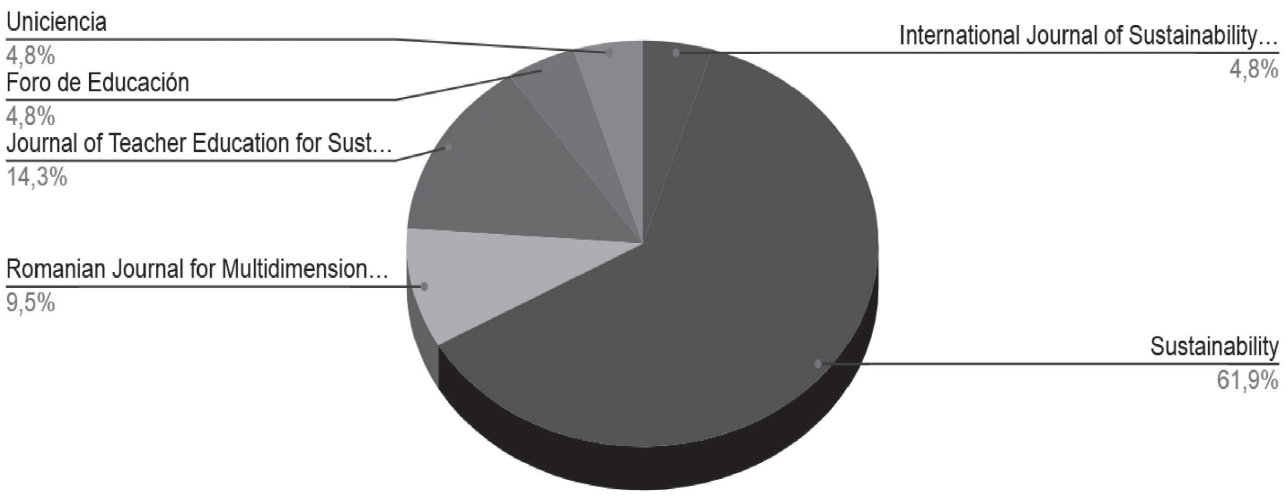

Regarding the authorship of the publications, 18 of the articles have between 2 and 5 authors and only 3 publications are signed by a single author. Furthermore, $55.5 \%$ of the authors are professionally affiliated to a Spanish university institution such as Barcelona, Seville, A Coruña, Granada, Cádiz, Salamanca and Jaén, compared to $44.5 \%$ who belong to international universities or scientific centers located in cities such as Gothenburg, Zaporizhzhia, Khmelnytskyi, Bucharest, Syndney, Tasmania, Chile, Ghana, Chandigarh, or Panjab. This leads us to point out that in this work we have selected research carried out worldwide in the Spanish, European, Latin American context or in countries such as Australia, Africa and India. This corroborates the importance of social responsibility in university students for the improvement of educational quality at an international level.

The selected publications are located in such contexts, with very similar samples, since most of them have worked with students studying at different educational study 
(Elementary Education, Early Childhood Education, Social Education and Pedagogy), programs dedicated to teacher training.

In relation to the type of methodology used in the publications, it can be seen that most of them are quantitative, since there are 16 studies, with qualitative research being a minority, and there are only 4 of the total, as well as there is only one study with a mixed methodology (Figure 4).

\section{Figure 4}

\section{Type of Methodology Used}

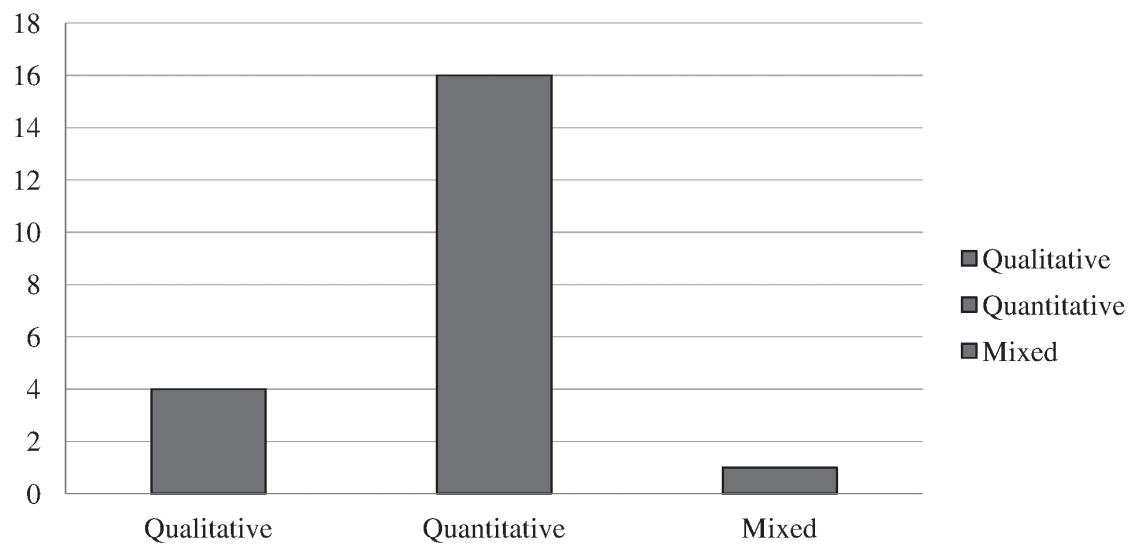

Finally, it is necessary to point out the key words included for their identification among the scientific community. The most relevant, due to their repetition in the different research studies selected, are the following: education for sustainable development; teacher education; student perception; higher education; teacher students, teacher training and preservice teacher.

\section{Professional Attitudes and Skills of Future Teachers Towards Sustainability}

Taking as a reference the perception of teachers in training on sustainable development (Table 1), research shows their favorable attitudes towards sustainability, social commitment to others and their environment, and social responsibility, considered to be major components in facing the problems and challenges affecting society today. This shows their interest in the development of sustainable initiatives, aimed at social transformation. It also underlines the implementation of positive values and attitudes that guarantee equal opportunities for all and a balance between economic growth, care for the environment and the social well-being of the people around us.

Based on the student's competences for the construction of a sustainable society, the papers reviewed reveal their partial approach to this issue. They focus on the development of practical skills related to environmental education, as most students relate sustainability to Natural Sciences, leaving in second place the economic field, associated with the development of equitable economic growth, as well as the social dimension linked to the promotion of values, ethics or the management of emotions, among other aspects. 
However, the lack of preparation of the student in education to develop such competences in their future profession is detected. It is considered that educators do not have the necessary skills to empower their students in the near future, changing the way they make decisions and take responsible actions in favor of the integrity of the environment, economic viability and social welfare of people.

\section{Table 1}

Synthesis of Research on Professional Attitudes and Skills of Future Teachers Towards Sustainability

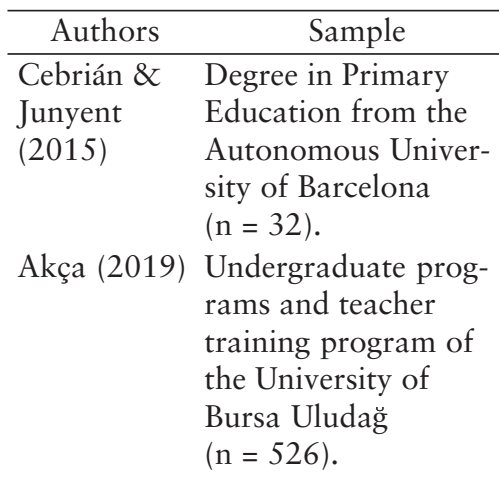

Álvarez Degree in Primary

et al. (2019) Education from two Spanish universities $(\mathrm{n}=274)$.

Olmos et al. Degrees in Early (2019)

\section{Varetska} et al. (2019) nal Institute, Ukraine. Postgraduate Pedagogical Education ( $\mathrm{n}=649$ ).

Manasia Undergraduate and et al. (2020) postgraduate studies from 15 faculties of the Polytechnic University of Bucharest, Romania ( $\mathrm{n}=312$ ). sity of Granada ( $\mathrm{n}=52$ ).

Results

Students tend to prioritize the acquisition of knowledge and practical skills related to nature and natural sciences, to the detriment of other types of learning such as the promotion of ethical values, positive attitudes towards sustainability and the management of emotions.

Future teachers are aware of the concept of sustainability; they show positive attitudes towards environmental awareness, the matching of people with positive values and attitudes and the development of skills to ensure appropriate behaviors. Beliefs about sustainable development appear to be stronger in the case of female students, as well as among those who have entered an undergraduate program at the Faculty of Education. Fourthyear students and those who are academically strong show stronger beliefs towards ESD.

Certain personal variables (gender, place of habitual residence or type of leisure activities undertaken by the student) and educational variables (studying a subject related to environmental education) have a significant impact on the acquisition of skills for sustainability. There is a high demand for implementing ESD from the Childhood Education Higher Education sector through innovative methods and Primary Educa- that emphasize the social responsibility of each particition from the Univer- pant as an individual, as well as the capacity to assume shared responsibilities and respond to situations of injustice.

It underlines the urgent need to create the right condi. tions for the development of social competence in future teachers, responding to the needs of society and implementing socially significant projects.

The relevance of knowledge, practice, professional commitment and self-management is highlighted as central variables for teacher training. Knowledge about ESD has a positive influence on teaching practice and professional engagement in the classroom, including respect for values, ethical behavior and responsiveness to peer feedback. 
Continuation of Table 1

Martínez Degrees in Infant and The student claims to be committed to others and their et al. (2020) Primary Education environment. Shows personal values towards Social Resfrom the University ponsibility. Demonstrates the need to combine their of Jaén and Granada future professional practice from social commitment and $(\mathrm{n}=572)$. sustainable education.

Muñoz Degrees in Primary et al. (2020) Education, Primary Education, Pedagogy and Social Education from the University of Salamanca ( $\mathrm{n}=326$ ).

Ortega Master of Teacher et al. (2020) Training in Secondary Education in Spanish, South American and European universities ( $\mathrm{n}=163$ ).

Vásquez Bachelor's degree in et al. (2020) Infant and Primary Education from a Chilean university ( $\mathrm{n}=145)$.

Nketsia Diploma in Basic et al. (2020) Education Program University of Ghana $(\mathrm{n}=167 ; \mathrm{n}=13)$.
Students in Pedagogy and Social Education obtain significant improvements in the development of their sustainability skills. In the Grade of Primary Education, a higher level of sustainability competencies can be seen in the first year than in the fourth year.

The agreement among students towards the promotion of conflict resolution strategies for social transformation is demonstrated. They express the need to develop critical and creative thinking skills for social intervention. There are no significant statistical differences in students' representations of ESD according to gender, age, institutional affiliation or previous education.

The students often link ESD with environmental education. They feel that they have sufficient skills to incorporate sustainability into their future professional practice, but they have general ideas.

The findings support a call for reforms that will ensure that the four key concepts in the SDG 4 (quality, inclusion, equity and lifelong learning) are well addressed in the Basic Education and Special Education Needs curriculum to promote inclusive education practices and values.

\section{Initial Teacher Training for Sustainable Development Education}

With regard to the level of training of teachers in education for sustainable development (Table 2), the research reviewed shows how students are convinced of the need and importance of addressing sustainability issues in higher education and, as a consequence, including ESD in their initial training process. The university contributes to the integral and critical education of its students, being a key element in the development of the responsibility and social commitment of future teachers as professionals committed to the progress towards the sustainability of the planet.

The incorporation of sustainable development in the curricula and university curricular designs of education (through the competences of the Degrees or Postgraduate courses, the contents for certain subjects or as complementary training) allows an improvement in the motivation and attitudes towards sustainable development in the student, at the same time as it favours the knowledge and practice of sustainable actions in their closest environment. Furthermore, it promotes learning spaces based on equity and equal opportunities, emotional education and values, citizen training and respect for human rights to facilitate life in society, as well as adequate decision-making to contribute 
to the construction of a sustainable future. It also allows the acquisition of didactic strategies to integrate this knowledge into their teaching practice in the context of sustainable education.

These proposals must be based on an analysis of the reality in which they are developed, as well as the needs of an environmentally responsible society. Furthermore, they must be supported by innovative teaching experiences that bet on the participation and protagonism of the student in a significant learning process, motivating them towards sustainable development and improving their professional skills for the construction of a world more committed to the environment.

\section{Table 2}

\section{Synthesis of Research on Initial Teacher Training for Sustainable Development}

\begin{tabular}{lll}
\hline \multicolumn{1}{c}{ Authors } & \multicolumn{1}{c}{ Sample } & \multicolumn{1}{c}{ Results } \\
\hline Andersson & Teacher training & The student's participation in a training course aimed at \\
et al. (2013) & $\begin{array}{l}\text { program of the } \\
\text { providing tools for teaching sustainable development }\end{array}$ \\
& $\begin{array}{l}\text { University of Gothen- } \\
\text { burg and the Univer- } \\
\text { sity West, Sweden } \\
(\mathrm{n}=323) .\end{array}$ & $\begin{array}{l}\text { perceptions, especially personal responsibility towards } \\
\text { and willingness to contribute to sustainability. }\end{array}$
\end{tabular}

Solís \& $\quad$ Master's degree in Valderrama Teacher Training in (2015) Secondary Education

After taking the sustainability course, significant changes at the University of Seville $(\mathrm{n}=30)$. can be seen among students in terms of their perspective on sustainability and the aims of ESD, which has implications for the role of the teacher and the concept of education itself.

Vega et al. Faculty of Education The model of teacher training based on the development (2015) of the University of Granada and A of sustainable skills through the resolution of socioCoruña $(\mathrm{n}=300)$. environmental problems favors a change in students' attitudes, as well as in their level of knowledge towards sustainability and their responsible behavior towards sustainable development.

Merritt Bachelor of Arts in The students consider it important to incorporate ESD

et al. (2018) Elementary Education into the future professional practice. Claim to have suffrom Arizona State ficient competencies to educate for sustainability, making University, USA $(\mathrm{n}=91)$. a difference in society. Participation in such a training course has not changed their perceptions about what actions are needed to develop positive societal changes in the future.

Dahl (2019) Teacher training program of different European universities $(\mathrm{n}=578)$.

Students feel that they are not trained enough to educate towards sustainability. This calls for the need to incorporate education for sustainability into initial teacher training programs, which is considered a major component of teacher professionalism.

Solís et al. Degrees in Early It shows how little ESD is present in initial teacher (2019) Childhood Education, training. Students underline their lack of preparation to Primary Education and Pedagogy from the University of Seville $(\mathrm{n}=219)$. develop sustainability competencies in their future teaching practice. They stress the need to reorient initial teacher education and to develop proposals for teacher innovation to improve their professional skills in this area. 
Continuation of Table 2

Androshchuk Khmelnytskyi

et al. (2020) National University, Ukraine $(\mathrm{n}=457)$.

García et al. Master in Educa(2020) tional Research of the University of Cadiz $(\mathrm{n}=32)$.

Sundh Degree in Primary

(2020) Education at Uppsala University (Sweden) $(\mathrm{n}=7)$
The students' participation in this experience has significantly improved their preparedness to incorporate sustainable development into their future professional practice. This improves the harmonious development among people, as well as between society and nature. Furthermore, it favors in the future teaching new principles based on the idea of preserving and enriching nature and promoting interaction between nature and people.

It demonstrates progress in improving student perceptions and knowledge of ESD. More emphasis is needed on the development of teaching strategies to integrate this knowledge into their future teaching practice and thus transmit skills, motivations and values to students that contribute to the well-being of society.

The results show that teacher students at an early stage in their education can benefit from applying their theoretical knowledge in school. Working one day a week at school makes them experience didactic dilemmas of different kinds that are useful in their preparation for a professional career as school teachers. Teacher education at universities, and particularly at minor campuses, need to find sustainable ways to attract young people to programs of teacher education in order to secure sustainable education at schools with qualified teachers in more rural areas of the countries.

These transformational educators should have sustainability conditioned deeper layers of consciousness so that their teaching, their choices should be able to reflect the essence of sustainability, hence further motivating the student teachers towards sustainability.

\section{Discussion}

Deepening the analysis of the current status of sustainability and the relationship with initial teacher education, according to Salite et al. (2021), would help create deeper personal meanings for sustainable education. The answer is that this work has allowed us to offer results of enormous interest that respond to some of the criteria/interests shown from the UNESCO Chair of the University of Daugavpils and the international network of Journal of Teacher Education for Sustainability (JTES) and Disourse and Communication for Sustainable Education (DCSE), as well as the United Nations General Assembly in the 2030 Agenda. In this sense, we delve into one of the goals expressed in the study by Murillo-Vargas et al. (2021) when we consider initial teacher education as a field of study of special importance expressed in a significant number of experiences and works analysed in this article.

The main findings reported in the scientific literature demonstrate the favorable attitudes of education students towards sustainability and their commitment to the environment. However, there is a deficit in the development of the professional competences 
needed to implement ESD in their future professional practice and thus contribute to the social welfare of the environment (Odell et al., 2020). The future teacher must be a committed citizen, capable of leading the new challenges posed by society (Merrit et al., 2019), and must therefore have a series of professional skills related to the development of a fairer, more sustainable and economically viable society (Álvarez et al., 2019; Solís et al., 2019; Muñoz et al., 2020), these being the ones that are needed:

- Know-how, referring to the development of personal approaches and the ability to act with greater autonomy, judgement and personal responsibility for sustainable development.

- Knowing how to learn, focusing on the need for society to learn and understand the challenges to be faced (both internationally and locally), as well as the potential role that current and future teachers can play in meeting those challenges.

- Know-how, linked to the development of practical skills in ESD.

- Knowing how to live together, emphasizing the need to develop cooperation and/or collaboration understanding of the importance of interdependence, pluralism and mutual understanding in the pursuit of the common good.

Also, we agree with Brandisauuskiene et al. (2021) when they highlight the importance of incorporating ESD for the improvement and quality in the training and professional development of future teachers from a collaborative-cooperative perspective. This statement deepens the idea expressed by Brandisauskiene et al. (2021, p. 167) when they state in their research paper that "collaborative teacher learning in initial teacher education has an impact on the performance of their school students and should be verified by separate research".

Our research verifies and offers a response to the study by Brandisauskiene et al. (2021, p.167) when the results obtained in our research work express the need to train, from a vision of sustainable development, the future teacher in a prioritized and critical way, creating an interest in producing knowledge and culture and, in this way, expanding their horizons more and more in the face of the need to develop critical and creative thinking skills for social intervention (Albareda et al., 2018; Ortega et al., 2020).

The need to promote ESD from the point of view of higher education is determined by its integration into university education plans. Future teachers must be supported and trained to understand the importance of their role in building a sustainable society, incorporating the "sustainability" component into their future professional practice (Vásquez et al., 2020). To achieve this purpose, it is essential that the work they do in their classroom is recognized and supported by the university as the institution that directs their training.

Authors such as Cebrian and Junyent (2015) and Olmos et al. (2019) stress the need to integrate ESD into higher education itself, being able to share innovations and good practices on sustainability, focusing the integration strategy on the teacher training plan and emphasizing social responsibility among its members. Muñoz et al. (2020) stress the importance of including practical training in the curriculum on issues related to environmental improvement, sustainability and community participation; this would increase the quality of skills among students at the end of their university studies and, therefore, the initial training of future teachers to better understand their environment and respond to new challenges (Leich et al., 2018). 
From this perspective, the professional development of the future teacher towards ESD allows for the development of a number of skills related to:

- An ecosystemic vision of reality and knowledge, based on the idea of preserving nature, enriching sustainable development and promoting interaction between nature and people (Androshchuk et al., 2020).

- An ability to combine the contribution of knowledge derived from different topics for the resolution of conflicts and/or problems, each one maintaining its own perspective when faced with a problematic situation (Akça, 2019).

- Awareness of responsibility as an individual and as part of society, so that when educating you are guided by ethics. Consequently, responsibility is understood from a social perspective of each participant, as well as the ability to assume shared responsibilities and respond to situations of injustice (Olmos et al., 2019), being aware of the importance of teaching and living the values of solidarity, sharing, cooperation, collaboration and equal opportunities (Veisson \& Kabaday, 2018).

In short, this research reveals the importance of education in promoting a society that is moving towards sustainable development. In this context, the role of the teacher in training, who will be responsible for the education of the younger generation in the near future, becomes important. The university must be committed to responding to the needs of the environment, incorporating ESD into the training plans of these education students. This will allow them to be "empowered" to face the new challenges of our society and to develop their future professional practice from the perspective of sustainability.

\section{Conclusions}

This work has recognized that our education experiences are critical to achieve the transition towards sustainability as they equip learners with the knowledge, skills and attitudes needed to reorient social structures and systems. Specifically, the initial teacher training sector is positioned to address sustainable development as it educates the future generation of leaders, challenges dominant paradigms and produces groundbreaking research. However, for Faculties of Education to meet their full potential in this regard, all aspects contributing to good-quality education need to be supported. One of the current core issues in higher education for sustainable development is the lack of the development of the professional competences needed to implement ESD in the future professional practice, thus contributing to the social welfare of the environment. This idea will be key because it is necessary to reorient teacher education curricula towards the development of skills, relations, high-quality ESD guidance and support if Faculties of Education are to contribute to a more sustainable future. Therefore, the most important task is to establish professional development approaches and opportunities that would enable teaching colleagues to prepare students, regardless of their courses or specializations in education training, to understand and apply their professional and global responsibilities in sustainability. In this sense, the research results haves shown that the selected theme is a good basis or possibility for collaboration among groups of Faculties of Education enabling discussion in Educational Sustainability Development among different institutional policies and cultures in initial teacher training for social welfare, justice and social equity of our students as future citizens of a global society. This is a matter of international concern, as the systematic review has shown. 


\section{References}

Akça, F. (2019). Sustainable development in teacher education in terms of being solution oriented and self-efficacy. Sustainability, 11(23), 6878. https://doi.org/10.3390/ su11236878

Albareda, S., Vidal, S., \& Fernández, M. (2018). Implementing the sustainable development goals at University level. International Journal of Sustainability in Higher Education, 19, 473-497. https://doi.org/10.1108/IJSHE-05-2017-0069

Alexander, P. A. (2020). Methodological guidance paper: The art and science of quality systematic reviews. Review of Educational Research, 90(1), 6-23. https://doi.org/ 10.3102/0034654319854352

Alkhawaldeh, A. (2017). School-based teacher training in Jordan: Towards on-school sustainable professional development. Journal of Teacher Education for Sustainability, 19(2), 51-68. https://doi.org/10.1515/jtes-2017-0014

Álvarez, O., García, L. Á., Salvà, F., \& Calvo, A. (2019). Variables influencing preservice teacher training in education for sustainable development: A case study of two Spanish universities. Sustainability, 11(16), 4412. https://doi.org/10.3390/ su11164412

Andersson, K., Jagers, S. C., Lindskog, A., \& Martinsson, J. (2013). Learning for the future? Effects of education for sustainable development (ESD) on teacher education students. Sustainability, 5(12), 5135-5152. https://doi.org/10.3390/su5125135

Androshchuk, I. V., Androshchuk, I. P., \& Komochkova, O. O. (2020). Building the content of teacher training in the context of education for sustainable development. Romanian Journal for Multidimensional Education, 12, 19-36. https://doi.org/ 10.18662/rrem/12.1sup1/221

Anyolo, E. O., Kärkkäinen, S., \& Keinonen, T. (2018). Implementing education for sustainable development in Namibia: School teachers' perceptions and teaching practices. Journal of Teacher Education for Sustainability, 20(1), 64-81. https://doi.org/10.2478/jtes-2018-0004

Brandisauskiene, A., Cesnaviciene, J., Miciuliene, R., \& Kaminskiene, L. (2021). What factors matter for the sustainable professional development of teachers? Analysis from four countries. Journal of Teacher Education for Sustainability, 22(2), 153170. https://doi.org/10.2478/jtes-2020-0022

Bertschy, F., Künzli, C., \& Lehmann, M. (2013). Teachers' competencies for the implementation of educational offers in the field of education for sustainable development. Sustainability, 5, 5067-5080. https://doi.org/10.3390/su5125067

Bulut, B., \& Çakmak, Z. (2018). Sustainable development education and its reflections on curricula. Türkçe Edebiyat Kültür Eğitim Dergisi Sayı Dergisi, 7, 2680-2697.

Cebrián, G., \& Junyent, M. (2015). Competencies in education for sustainable development: Exploring the student teachers' views. Sustainability, 7(3), 2768-2786. https://doi.org/10.3390/su7032768

Dahl, T. (2019). Prepared to teach for sustainable development? Student teachers' beliefs in their ability to teach for sustainable development. Sustainability, 11(7), 1993. https://doi.org/10.3390/su11071993

Darling-Hammond, L., Hyler, M. E., \& Gardner, M. (2017). Effective teacher professional development. Learning Policy Institute. 
García, E., Jiménez, R., \& Azcárate, P. (2020). Education for Sustainability and the Sustainable Development Goals: Pre-service teachers' perceptions and knowledge. Sustainability, 12(18), 7741. https://doi.org/10.3390/su12187741

Heasly, B., Lindner, J., Iliško, D., \& Salìte, I. (2020). From initiatives, to insights, to implementation of the sustainability and securitability Agenda for 2030. Discourse and Communication for Sustainable Education, 11(1), 1-4. https://doi.org/10.2478/ dcse-2020-0001

Howlett, C., Ferreira, J. A., \& Blomfield, J. (2016). Teaching sustainable development in higher education: Building critical, reflective thinkers through an interdisciplinary approach. International Journal of Sustainability in Higher Educucation, 17(3), 305-321. https://doi.org/10.1108/IJSHE-07-2014-0102

Jetly, M., \& Singh, N. (2020). Analytical study based on perspectives of teacher educators in India with respect to education for sustainable development. Journal of Teacher Education for Sustainability, 21(2), 38-55. https://doi.org/10.2478/jtes-2019-0016 Joseph, C., \& Said, R. (2019). Student engagement: Catalyst to achieve the Sustainable Development Goal. In W. Leal-Filho, A. Azul, L. Brandli, P. Özuyar, \& T. Wall (Eds.), Quality education. Encyclopedia of the UN Sustainable Development Goals (pp. 812-820). Springer International Publishing.

Leicht, A., Heiss, J., \& Byun, W. J. (2018). Issues and trends in Education for Sustainable Development. UNESCO Publishing.

Manasia, L., Ianos, M. G., \& Chicioreanu, T. D. (2020). Pre-service teacher preparedness for fostering education for sustainable development: An empirical analysis of central dimensions of teaching readiness. Sustainability, 12(1), 166. https://doi.org/10.3390/ su12010166

Martínez, E., Pegalajar, M., \& Burgos, A. (2020). Social responsibility and University teacher training: Keys to commitment and social justice into schools. Sustainability, 12(15), 6179. https://doi.org/10.3390/su12156179

Merritt, E., Hale, A., \& Archambault, L. (2019). Changes in pre-service teachers' values, sense of agency, motivation and consumption practices: A case study of an education for sustainability course. Sustainability, 11(1), 155. https://doi.org/10.3390/su 11010155

Muñoz, J. M., Sánchez, F., Barrón, Á., \& Serrate, S. (2020). Are we training in sustainability in higher education? Case study: Education degrees at the University of Salamanca. Sustainability, 12(11), 4421. https://doi.org/10.3390/su12114421

Murillo-Vargas, G., Gonzalez-Campo, C. H., \& Brath, D. (2021). Mapping the integration of the Sustainable Development Goals in Universities: Is it a field of study? Journal of Teacher Education for Sustainability, 22(2), 7-25. https://doi.org/10. 2478/jtes-2020-0013

Nketsia, W., Opoku, M., Saloviita, T. \& Tracey, D. (2020). Teacher educators' and teacher trainees' perspective on teacher training for sustainable development. Journal of Teacher Education for Sustainability, 22(1), 49-65. https://doi.org/10.2478/jtes2020-0005

Odell, V., Molthan-Hill, P., Martin, S., \& Sterling, S. (2020). Transformative education to address all sustainable development goals. In W. Leal-Filho (Ed.), Springer Nature Switzerland AG 2019: Encyclopedia of the UN Sustainable Development Goals (pp. 905-916). Springer. 
Olmos, M., Estrada, L. I., Ruiz, F., López, R., \& Mohamed, L. (2019). Making future teachers more aware of issues related to sustainability: An assessment of best practices. Sustainability, 11(24), 7222. https://doi.org/10.3390/su11247222

Ortega, D., Alonso, A., \& Corbí, M. (2020). Socio-environmental problematic, endpurposes, and strategies relating to Education for Sustainable Development (ESD) through the perspectives of Spanish secondary education trainee teachers. Sustainability, 12(14), 5551. https://doi.org/10.3390/su12145551

Öztürk, M. (2017). Education for Sustainable Development: Theoretical framework, historical development, and implications for practice. Elementary Education Online, 16,1-11. https://doi.org/10.17051/ilkonline.2017.342997

Salite, I., Fjodorova, I., \& Ivanova, O. (2021). Does the JTES help us create deeper personal meanings for sustainable education? Journal of Teacher Education for Sustainability, 22(2), 1-6. https://doi.org/10.2478/jtes-2020-0012

Solís, C., \& Valderrama, R. (2015). Education for a sustainable future in teacher training. What are we doing? Foro de Educación, 13(19), 165-192. https://doi.org/10.14516/ fde.2015.013.019.008

Solís, C., Ruiz, J., Limón, D., \& Valderrama, R. (2019). Sustainability in the University: A study of its presence in curricula, teachers and students of education. Sustainability, 11(23), 6620. https://doi.org/10.3390/su11236620

Sundh, S. (2020). Establishing sustainable teacher education with weekly school practice Identifying teacher students' experiences of didactic dilemmas in the Swedish primary school classroom. Journal of Teacher Education for Sustainability, 22(1), 37-48. https://doi.org/10.2478/jtes-2020-0004

Sunthonkanokpong, W., \& Murphy, E. (2019). Quality, equity, inclusion and lifelong learning in pre-service teacher education. Journal of Teacher Education for Sustainability, 21(2), 91-104. https://doi.org/10.2478/jtes-2019-0019

UNESCO. (2018). Progress on Education for Sustainable Development and Global Citizenship Education. United Nations. https://unesdoc.unesco.org/ark:/48223/ pf0000266176_spa?posInSet=1\&queryId=56e66126-33e0-4c4b-b491-85968586 ac15

United Nations. (2015). Transforming our world: The 2030 Agenda for Sustainable Development. https://sustainabledevelopment.un.org/post2015/transforming ourworld

Urrútia, G., \& Bonfill, X. (2010). Declaración PRISMA: Una propuesta para mejorar la publicación de revisiones sistemáticas y metaanálisis [PRISMA Statement: A proposal to improve the publication of systematic reviews and meta-analyzes]. Medicina clínica, 135(11), 507-511. https://cutt.ly/qyFsDKJ

Varetska, O. V., Nikulochkina, O. V., Tonne, O. S., Kuzminskyi, A. I., Bida, O. A., \& Vdovenko, V. V. (2019). Primary school teacher's social competence in the postgraduate education. Romanian Journal for Multidimensional Education, 11, 309_ 327. https://doi.org/10.18662/rrem/192

Vásquez, C., Seckel, M. J., \& Alsina, Á. (2020). Belief system of future teachers on Education for Sustainable Development in math classes. Uniciencia, 34(2), 1-30. https://doi.org/10.15359/ru.34-2.1

Vega, P., Varela, M., \& Álvarez, P. (2015). Evaluation of an educational model based on the development of sustainable competencies in basic teacher training in Spain. Sustainability, 7(3), 2603-2622. https://doi.org/10.3390/su7032603 
Veisson, M., \& Kabaday, A. (2018). Exploring the preschool teachers' views on professionalism, quality of education and sustainability: International study in Estonia and Turkey. Journal of Teacher Education for Sustainability, 20(2), 5-18. https://doi.org/10.2478/jtes-2018-0011

Correspondence concerning this article should be addressed to María del Carmen Pegalajar Palomino, professor, Faculty of Humanities and Educational Sciences, Department of Pedagogy, Universidad of Jaén, Campus Las Lagunillas s/n. 23009, Jaén, Spain. Email: mcpegala@ujaen.es 